\title{
Szakmai élettörténeti interjú Révész Magdával
}

Bányai Emö: Kérlek, meséld el a szakmai élettörténetedet! Nem szólunk közbe, amíg mesélsz, addig félretesszük a kérdéseinket, aztán majd ha befejezted, akkor kérdezünk.

Révész Magda: Jó. Először is: régészkedtem, hoztam nektek két leletet, arra kérlek, hogy nézzétek meg és mondjátok meg, hogy melyikből mi lett! Szívesen hagyok rá időt, hogy megnézegessétek. Emő azt kérte, hogy a szakmai személyes történetemet és a szociális munka történetét rakjam össze. Megpróbáltam összeírogatni, hogy mit akarok elmondani, remélem, hogy izgalmas, meg érdekes lesz. Ha valamit nem értetek, tehát nem plusz kérdésetek, hanem értelmezési kérdésetek van, akkor kérdezzetek közbe, hisz fel van írva, amit mondani akarok, úgyhogy megpróbálom majd folytatni.

Én magam pszichológusként végeztem, és úgy képzeltem az életemet, hogy gyerekpszichológusként fogok dolgozni. El is mentem egy nevelési tanácsadóba dolgozni, és az első nap szembesültem azzal, hogy a beosztásom úgy hangzik, hogy családgondozó, mert családgondozó helyén voltam, amit egy darabig nem vettek komolyan, de aztán később igen. Egy olyan nőtől tanultam a családgondozást, akit ma úgy hívnak, hogy Almási Judit. Egy csomó mindent elmagyarázott nekem, amit aztán nem nagyon hasznosítottam, mert szeptemberben mentem oda, és az első félévben, tehát decemberig dolgoztam családgondozóként, de akkor elküldtek a harmadik kerületbe egy családgondozói tanfolyamra, amit pedig Hegyesi Gábor vezetett. Ha tudjátok, hogy mennyi ember tűnt el a színről, akkor furcsa, hogy mind a ketten megmaradtak, és ilyen nagy nevek lettek. Amit megtanultam és ami nagyon fontos a szociális munkában az az, hogy a „mintha” tér és a valóságos tér az két dolog. Az az anyag, amivel egy pszichológus dolgozik, ami úgy néz ki, hogy bejön hozzá egy páciens és elmondja az életét, de nem mutat meg semmit, hanem csak a szavaival elmondja. Tehát a pszichológus azzal dolgozik, amit a páciense elmond, ha ez egy totális hazugság, akkor azzal dolgozik, míg a családgondozó, így a szociális munkás a valóságos térben dolgozik, a szeme előtt zajlanak a családi krízisek, megnézi a gyereket az iskolában, beszél a pedagógusokkal és nem csak azzal dolgozik, amit a páciens megoszt vele. Ez végigkísérte az én szakmai életemet, mert amiért én szociális munkás lettem, az pontosan a „mintha” tér és a valóságos tér összeütközése. A nevelési tanácsadó volt az az intézmény, ahol - ha végigtekintjük a gyerekekkel foglalkozó intézmények történetét visszafelé családgondozókat, azaz a szociális munkások őseit alkalmazták. Az volt a feladatuk, hogy megnézzék a gyereket abban a közegben, amiben mozognak, iskolában, óvodában, családban. Beszéljenek a szülökkel, és meg lehessen válaszolni azt a kérdést, hogy az a gond, ami a gyerekkel van, vajon miből fakad és miben tud segíteni, mibe tud belenyúlni anélkül, hogy nagyobb kárt okozna. Így kerültek a családgondozók a nevelési tanácsadóba, és ez nagyon jól is müködött. Mint mondtam, három hónapig tanultam a családgondozást, majd elkezdtem gyerekpszichológusként dolgozni, de egy év múlva el kellett jönnöm, mert visszajött gyesröl az, akinek a helyén voltam, így elmentem egy másik nevelési tanácsadóba.

Itt együtt dolgoztam Vaskuti Pállal és egy olyan dolgot kezdeményeztünk, ami nagyon erősen lökött afelé, amit ma csinálok, és belejátszott abba, hogy én nem pszichológusként, hanem szociális munkásként dolgozom immár borzalmasan sok - mondjuk 26 - éve. Beindítottunk egy kamasz csoportot. Volt a gyámhatóságon két fiatal tisztviselö, akik egyszer írtak nekünk egy levelet, ami úgy hangzott, hogy M. Misi nagy gazember, telefonfülkéket gyújtogat és 
látták őt átbiciklizni a Kosztolányi Dezső téren a piros lámpánál, keresztül-kasul, és úgy gondolják, hogy segítségre van szüksége és tegyük meg, hogy segítünk neki. Ez akkor egy borzalmasan nagy pofon volt (pozitív értelemben), mert úgy gondoltuk, hogy a gyámhatóságon csak ilyen körmüket reszelö, borzalmas, kibírhatatlan hivatalnokok dolgoznak, nem gondoltuk, hogy segítséget tudnak kérni egy gyerek ügyében. Szégyelltük magunkat feltételezésünk miatt. Abban a nevelési tanácsadós közegben, ahova a szülők jöttek be gyerekeikre panaszkodva, ez teljesen idegen jelzés volt. Ezt hívják úgy, hogy a jelzőrendszer müködik, ami akkor pedig még nem létezett. Akkor felhívtuk a gyámhatóságot, és elkezdtünk velük barátkozni, ez a barátkozás a mai napig megmaradt. Az egyik gyámhatósági előadót úgy hívják, hogy Bán Gabriella, nem tudom, hogy ismeritek-e. Most ismét gyámhatóságon dolgozik, de a gyermekvédelmi törvény megszületése elött az első gyermekjóléti szolgálatot ő hozta létre a IX. kerületben, ez volt a Fehér Holló, nem tudom, így hallottatok-e róla. A másikat pedig úgy hívták, hogy Németh László, de ez nem az a Németh László, aki szintén jön ide és aki a szociális levelezőlistát pásztorolja, hanem a jogász Németh László, és családsegítők, gyerekjólétik jogi tanácsadója, a mienk is. Azóta, mióta a XI. kerületböl eljöttem, végigkíséri szakmai életemet, mint jogi segítségnyújtó.

Egy kiskamasznak, nevezzük Zolinak, köszönhetem, hogy elkezdtünk gondolkozni azon, hogy mi legyen azokkal a gyerekekkel, akikkel nem tudunk „fehér köpenyes” módon foglalkozni - nem egy klasszikus terápiára van a kamasz gyereknek szüksége, hanem hogy dumálhasson, hogy ott lehessen, hogy megérthessék, szóba állhasson, megtapasztalhassa, hogy nem minden felnőtt hülye. A kamaszok elkezdték a nevelési tanácsadót abból a munkarendböl kirobbantani, hogy kilencre jön egy gyerek, aztán háromnegyed tíztől tízig az ember lejegyzeteli, vagy kávézik, vagy cigizik, dumál, aztán később pótolja a jegyzeteket, és tízkor jön a következő gyerek, tizenegykor jönnek a szülök, akikkel anamnézist vesz fel; mert ezek a gyerekek időről időre megjelentek. Csináltunk egy kamasz csoportot, nagy nehézségek árán, természetesen péntek délután, mert túl hangosak ezek a gyerekek. Akkor csináltunk egy kamasz tábort, ami nagyon érdekes volt, hogy honnan gründoltuk össze a pénzt, de ez már egy másik történet. Mindenesetre elvittük öket Almádiba, a kempingbe egy hétre táborba. Az iszonyat volt, borzalmas volt. Az első nap loptak a közértböl, a közértes néni feljelentett bennünket, a második nap betörtek a kemping recepciójába - szóval iszonyat volt. Kézben tartottuk a dolgokat: a második nap elhatároztuk, hogy gyereket többet soha táborba nem viszünk. Mindenesetre ennek az volt a tanulsága, hogy a hét végére a gyerekek mégis elkezdtek közösségként müködni, és volt egy olyan tanulságuk, hogy a saját maguk által felállított szabályokat saját maguknak nem lehet megszegni. Ellenben nem olyan nagyon maradhattunk ott a nevelési tanácsadóban. Ennek pedig az volt az oka, hogy kitaláltuk, hogy a kamasz gyerekek, akik harcban és haragban állnak mind a családjukkal, mind a világgal, ha ezeket ott hagyjuk a hét 168 órájából mondjuk 166 órában, vagy 160-ban abban a közegben, ahol vannak, akkor nagyon nehéz nekik létezni. Ezért kitaláltunk egy olyan intézménytípust, amit TINCS-nek neveztünk el, ami úgy nézett volna ki, hogy oda a szülök és a gyerekek közös kérése alapján kerül be a gyerek, ami megadja a lehetőséget, hogy egy nagyon rövid időre mind a két természetes közegből, a családból is és az iskolából is kiemeljük, és a család rendszeres bejárása mellett megpróbálunk nekik egy védett közeget biztosítani. Maximum három hónapig járhat oda az iskolába és lakhat is ott, három hónap múlva eldöntjük, hogy visszamegy-e a korábbi iskolájába - ez akkor van, ha a családban volt a nagyobb zür -, vagy pedig hazaköltözik és a védett, belső iskolába jár továbbra is, ha az iskolában volt a nagyobb zür. Így egy fél év alatt, maximum egy tanév alatt rendezzük, és akkor mindenki visszamegy 
oda, ahova való. És akkor most megkérdezem, hogy van-e gondolatotok arról, hogy hogy hívják ezt az intézményt?... Gyerekek átmeneti otthona. És ez volt 1984-ben. Nem dolgom történelemórát tartani, de annak is van egy hosszan elmesélhető története, hogy hogyan fúrták meg ezt az intézményt. Azt kell mondanom, hogy megelőztük a korunkat, nagyon érdekes harcot folytattunk Vaskuti Pállal közösen annak érdekében, hogy ez az intézmény müködjön, kísérleti jelleggel. Voltunk a Parlament elnökénél, voltunk a pártbizottság elnökénél, voltunk a Fővárosi Tanács Mủvelődési Osztálya vezetőjénél, akit úgy hívtak, hogy Mezei Gyula. Voltunk a Parlament mellett müködö Ifjúsági Bizottság elnökénél, mindenki nagyon támogatott minket, kaptunk egy épületre ígérvényt akkor, ha szerzünk felújítót és kaptunk ígérvényt a müködtetésre való pénzre, ha írásba kapjuk, hogy adnak egy épületet, de a két szervezet nem volt hajlandó egy asztalhoz leülni. Szerintem telefonon megbeszélték, hogy így fognak bennünket tönkretenni. Igazából amit mondani tudtak, hogy nekünk nincs gyerekotthonos tapasztalatunk, és mit gondolunk mi, hogy tudnánk müködtetni egy intézményt, ami hasonló egy gyerekotthonhoz. És akkor mindketten elmentünk gyerekotthonba dolgozni, és nem maradtunk tovább nevelési tanácsadóban. Elmentünk a Kossuth Gyerekotthonba, ami ma a Menyecske utcában van, ami arról híres, hogy az volt az első olyan hely, amit a nyolcvanas években - hosszú idő után - eleve gyerekotthonnak építettek. Építészetileg is nagyon érdekes, mert van benne egy nagy közös tér, és amibe azt álmodták bele, hogy saját konyhája van minden gyerekcsoportnak, tehát hét végén vállalhatják azt, hogy föznek, mert korábban azt mondták, hogy az állami gondozott gyerekek azt hiszik, hogy a boltban vajas kenyeret lehet kapni párizsival a tetején, meg soha nem láttak kenyeret felvágatlanul. Ehhez képest nagy előrelépés volt, hogy így volt építve. De most visszakanyarodom az előző történethez, mert a Kossuth Gyerekotthon akkor még nem ott volt, hanem két részlege volt, az egyik a Mátyás király úton, a másik a Szilasi úton, a tündérhegyi pszichoterápiás intézet fölött, egy gyönyörüséges szép helyen és neurotikus fiúk otthona volt, ahova Vaskuti Pállal „beköltöztünk” még két pszichológussal kiegészülve. Az intézet igazgatója egy szörnyü alak volt, ő hál' istennek eltünt a színröl, de hogy a végét mondjam, behívott gyerekeket a szobájába, és jól megverte őket, ez volt a „pszichológusi” tevékenysége. Ott próbálkoztunk két évig pszichológusként dolgozni, ott is nagyon sok probléma és feszültség volt, de ez most itt nem annyira érdekes. Mindenesetre közben elmentek azok az emberek, akik az ígérvényt tették, illetve megszüntek azok a kapcsolataink, akikből összeállt volna a TINCS pedagógusgárdája - elmentek ide-oda dolgozni. Hiszen előtte megvolt mindenki, akit megálmodtunk, pedagógusok, pszichológusok, de addigra szétspriccelt ez a társaság. Mikor lehetetlenné tettek minket a gyerekotthonban, akkor elmentem még egy évre egy Szakoktatási Nevelési Tanácsadó címü céghez, amely a középiskolások számára volt egy vegyes felvágott nevelési tanácsadó. A jogi egyetemmel szemben egy lakásban müködött. Ott úgy dolgoztak a pszichológusok, hogy minden nap egy másik középiskolába mentek rendelni, az is egy iszonyat volt. A takarítónőnél talán egy kicsit magasabbra értékeltek bennünket, de nem akartak szobát adni az iskolákban, nem gondolták, hogy nekünk jogunk lenne a pedagógusokkal beszélni, a legtöbb helyen beraktak bennünket az orvosi szobába, általában a vetkőzőbe, hogy a gyógyszerszekrényhez ne férjünk hozzá. A rossz gyerekeket beküldték hozzánk - jó esetben -, rossz esetben meg ültünk és gondolkodtunk, hogy mit tudnánk tenni azért, hogy a gyerekhez jussunk. Egy olyan fiú volt, akivel én ott szóba tudtam állni, öt is büntetésből küldték le, máig megvan a kapcsolat, a mostani munkahelyemen is meglátogatott, és máig fontos élmény neki az, hogy akkor foglalkoztam vele és az anyukájával, aki egy szörnyeteg volt. 
Itt egy nagyon szubjektív és szakmaiatlan, véletlenszerü esetet elmesélek nektek. 1987-et írtunk akkoriban, januárban leesett egy korábban sohasem látott mennyiségü hó, 60-80 centi, majd jött egy iszonyatos hidegfront, ami után mínusz 20 fok lett. Olyan állapotok voltak Budapesten, hogy jégcsákánnyal vágtak utat arra, hogy az emberek át tudjanak menni a zebrán, a jégtömböktől nem lehetett kilátni az úttestre. Ez volt az az időszak, amikor én szembesültem azzal, hogy nincs ember, aki számontartaná, hogy én kedden, szerdán, csütörtökön és pénteken megjelenek-e azon a helyen, ahová a munkám szólít. Kb. egy hónappal később a fönököm nem engedett el egy hétre tanév közben síelni - amit nekem muszáj volt -, ekkor úgy döntöttem, hogy én mégis elmegyek síelni. Egy munkatársamnak szóltam, hogy ha keresnek, akkor tudjon róla. Bejelentettem a fönökömnek, hogy nem tudok hétfön teamre menni, és elmentem boldogan síelni. Mikor hazajöttem, akkor felhívott Gosztonyi Géza telefonon, és azt mondta, hogy ő vezet egy családsegítő szolgálatot, és menjek oda dolgozni, merthogy az milyen jó hely. Szombaton este találkoztunk is. Gosztonyi Géza szociológus volt, én egyetemista koromból ismertem őt, egypárszor buliztunk is együtt. Tudjátok-e, hogy a családsegítők története miből indul? Volt egy kétkötetes ún. Zöld könyv ${ }^{1}$. Arról hallottatok-e? És a társadalmi beilleszkedési zavarok kutatási főirányról? Nem kell, hogy halljatok, de ha szociálismunka-történettel akartok valaha foglalkozni, akkor azt a könyvet szerezzétek meg, nagyon érdekes, nagyon tanulságos. Az első kötetében leírják azokat a kutatásokat, amiket a különféle - nem természettudományi - kutatóhelyeken folytattak, társadalomtudományi intézetben, pszichológiai intézetben, ami már volt és ahol kutatták azt, hogy milyen beilleszkedési zavarok figyelhetők meg a társadalomban. Azt gondolták, hogy a szocializmus egy tökéletes rendszer, tehát ha olyan probléma van, ami a lélekkel vagy a fejjel kapcsolatos, az beilleszkedési zavar, ha abba a tökéletes társadalomba nem tud valaki beilleszkedni, az az ö hibája. Ez volt a címe, de magában a kötetben sok helyen megjelenik az, hogy milyen az a társadalom, amibe nem tud beilleszkedni. Nem arról van szó, hogy az egyéni hibák nehezítik a kapcsolódást egy tökéletes társadalomhoz, hanem a társadalomban vannak olyan problémák, amikről kevéssé beszélünk, amiket kevéssé mutatunk be, és talán nem az ember hibája, hanem a társadalom problematikája is belejátszik abba, hogy nem megy ez a beilleszkedés olyan tökéletesen. A másik kötetben össze volt gyüjtve, hogy a többi országban milyen lépéseket tesznek, és mi tehető nálunk annak érdekében, hogy megsegítse az embert, illetve nyitottá tegye a társadalmat arra, hogy a kis másságokat is befogadja. Szó volt arról, hogy mi a munkanélküliség, ami hivatalosan akkor nem is létezett - és mégis létezett -, mi a hajléktalanság és mi a szegénység, illetve szó volt arról, hogy mi a gond az iskolarendszerben. Tehát amit most hallotok a tévében, rádióban, hogy az iskola megnöveli azokat az induló különbségeket, ami a gyerekek között van, azt Ferge Zsuzsa leírta a hetvenes években, a TBZ-kutatás összesítőjében is benne van. Az iskola régen a hozott anyagból dolgozók mintájára működött, azaz a tanár megnézte, hogy milyen gyerekek ülnek a padban, és megpróbált nekik kitalálni egy olyan tematikát, egy olyan tanulási módszert, könyveket, amit az a gyerektársaság bír. Ezzel szemben a kialakult iskolarendszer elképzelt magának egy hatéves gyereket és elképzelte tizenöt vagy tizennégy éves koráig, hogy hogyan kíséri végig, hogy az elvégezze az általános iskolát. Minél erősebben elöírta a folyamatot, annál kevesebb gyerek felelt meg annak, hogy klasszikusan ezt a folyamatot végig tudja csinálni. Annál inkább fogadta be a polgári családban felnövő, jól szocializált, iskolaérett gyereket és annál inkább próbálta kilökni magából azokat a

\footnotetext{
${ }^{1}$ Andorka Rudolf, Pataki Ferenc et al. (1986): Társadalmi beilleszkedési zavarok Magyarországon. Budapest, Kossuth Könyvkiadó.
} 
gyerekeket, akik ebbe a megálmodott körbe nem illettek bele. Ez nem magyar sajátosság természetesen, de erről most nem mesélek. Ezeket a problémákat írta le ez a bizonyos TBZ kutatási föirány, és a második kötetben leírásra került valami, amit azóta sem értek, hogy megvalósítottak, amit úgy hívnak, hogy családsegítő szolgálat, amit kísérletként létrehoztak. 1985 márciusában nyitották meg, és úgy tudom, hogy tíz ilyen volt az országban - erröl egyébként vita van a szakmában -, különböző intézménytípusokon. Úgy volt kitalálva, hogy ez a tíz intézmény ne tárgyaljon egymással, hanem mind a tíz próbálja meg a saját útját megtalálni, és volt egy olyan ember, aki meg volt bízva azzal, hogy nézzen rá erre a tíz családsegítőre és próbálja meg a végén levonni a tanulságot, hogy ne legyenek egyformák, hanem legyenek különbözőek és nézzük meg, hogy melyik müködik és melyik nem. Aki ismeri a történelmet, az tudja, hogy 1985 az már a rendszerváltás előtti felfordulás kora, úgyhogy a nagy, piszkos semmibe veszett ez az elképzelés, nem is érdemes róla beszélni.

De visszatérve az én egyéni történetemhez, 1987 februárjában, mikor megkeresett engem Gosztonyi Géza, hogy menjek oda dolgozni, akkor ő a Terézvárosi Családsegítőnek volt a vezetője. A X. kerületben volt a másik. Ott a X. kerületnek csak az egyharmada volt az ellátási területe, mert ebben a TBZ-kutatásban az volt leírva, hogy 30000 lakosonként érdemes létrehozni egy ilyen családsegítő központot, azért, hogy a közösségi munkát - persze nem így hívták -, tehát hogy rálásson arra a társadalmi közegre, amely azon a helyen lakik. Köbányán 90000 ember lakott, így az új szolgáltatás a harmaduknak szólt, Terézvárosban az egész kerületre. Ott van az a nagyon sajátos dolog, hogy a Hegedü utcában van azóta is a családsegítő, ha kimegyünk a Hegedű utca végére és átmegyünk a Király utca (Majakovszkij utca) másik végére, akkor már a hetedik kerületben vagyunk, tehát nagyon a szélén volt a kerületnek, amiből aztán mindenféle feszültségek származtak. A VII. kerületit 1989-ben hozták létre, tehát a terézvárosi négy évig müködött úgy, hogy a szomszéd kerületben nem volt.

Akkor én szombat este beszéltem Gosztonyi Gézával síelésböl hazaérkezve, és vasárnap este felhívtam azt a kollegámat, aki azzal volt megbízva, hogy kísérje figyelemmel az én ott nem létemet, aki azt mondta, hogy senkinek nem tünt fel, hogy én nem voltam ott, nem hiányoztam senkinek, nem lesz semmi gond. Akkor én vasárnap este felhívtam Gézát és azt mondtam, hogy megyek. Beleugrottam valamibe, amiröl nem tudtam, mi az; már szombaton hosszú és fontos beszélgetést folytattam Gézával arról, hogy mi a családsegítő. Belecsusszantam egy olyan társaságba - most egy kicsit csúszkálok az időben, mert 87 öszén nem mindenki dolgozott ott -, ahol együtt dolgozott, vagy egy munkahelyi csoportban dolgozott Gosztonyi Géza, Mezei Gyuri, ősztől Diósi Ági, Bognár Szabolcs, Migács Tibor, Morvai Bea - ôt ma Varga Beának hívják. Ott az első hat évben - amit én fontosnak tartok a TECSA történetében - 1993-ig, míg a szociális törvény meg nem született - vérre menő viták zajlottak szociális szakemberek között, amik két téma köré csoportosíthatóak. Az egyik úgy hangzik, hogy „Halat adni, vagy halászni tanítani?”. Ez a 80-as évek végén egy alapvető kérdés volt, és a válasz sok ember számára az életet vagy a halált jelentette - és most ezzel nem viccelek vagy túlzok. A másik úgy hangzik (fel is írtam, hogy kameraképessé tegyem), hogy „Prostituálódni vagy szüznek maradni?”. Ez a szociális munkások számára nagyon fontos kérdés és a kliensekre is nagyon fontos hatással van. Ha meggondoljátok, hogy nem volt még szociális törvény, nem volt garantált segítség, segély, a családsegítők mégis a települési tanácsok (azaz önkormányzatok) fenntartásában müködtek, akkor nagyon könnyen belátható, hogy a szociális munkások a kliensek védelmében, a saját kenyéradó gazdájuknak mentek neki és olyan kompromisszumokat kellett, hogy kössenek a saját fennmaradásuk 
érdekében, amit a harcosabb szociális munkások nehezen türtek és nagyon könnyen neveztek az intézményért felelős vezetőket - mondjuk Gézát - prostituáltnak, hogy eladja a lelkét a fenntartóinak annak érdekében, hogy intézmény legyen, hogy fizetés legyen, hogy fütés legyen. Aki ismeri Mezei Gyuri személyiségét, meg Bognár Szabolcsét, Diósi Ágiét, az el tudja képzelni, hogy milyen viták, ordítozások és fenyegetések mentek ebben a társaságban, ami szakmailag nagyon érdekes volt, egyébként nagyon nehezen viselhető életet jelentett az első években. Mielőtt a gyerekjólétire rátérnék, három olyan kérdést fogok feltenni, ami a családsegítőben felmerült, és azt gondolom, hogy fontos a szociális munka története szempontjából. Ez pedig az, hogy nagyon korán, 87-88-ban már felmerült az a kérdés, hogy segélyezzen-e a szociális szakember. Ez egy nagyon könnyen megválaszolható kérdés volt, amíg a szociális törvény nem lépett életbe. Akkor még nem volt garantált segélyezés, tehát nem lehetett azt válaszolni erre a kérdésre, hogy a családsegítő ne segélyezzen. De nagyon nehezen megvalósítható kérdés volt. Gondoljátok végig, hogy 8-10 segítő szakember dolgozott személyenként 50-60-80 családdal, amit a kerületi tanácsok boldogan „odaadtak”, és minden „problémás” klienst odaküldtek a családsegítőbe, akit ök nem szerettek volna segíteni, mert a segélyezés az nem rászorultsági, hanem érdemességi alapon dőlt el, illetve empátiás alapon a tanácsok ügyintézői, azaz köztisztviselői részéről. Gondolom, el tudjátok képzelni, milyen nehéz volt eldönteni, hogy például Diósi Ági virágot áruló cigány asszonya kapjon-e az engedély nélküli virágárulás miatt rá kirótt büntetés kifizetésére pénzt, vagy a másik család lakbérhátralékra, vagy a harmadik a gyereknek szemüvegvásárlásra. Mindeközben mindenki tudta, hogy lényegében a segítő szakembernek nem kellene vállalni a segélyezés feladatát, hisz az nehezen egyeztethető össze a szociális segítő munkával. Ez nagyon nehéz időszak volt, de nem mondom, hogy rossz volt. Egy nagyon izgalmas, gyönyörüséges időszak volt az én szakmai életemben, aminek voltak olyan nehézségei, aminek nem örülök, de a legtöbbjének mégiscsak örülök.

Az volt tehát az egyik kérdés, hogy segélyezzen-e a családsegítö. A másik az önkéntesség szentsége, tehát hogy foglalkozzunk-e olyan családdal, amely nem akar segítséget kérni, de tudjuk, hogy segítségre lenne szüksége. És nagy kérdés az is, hogy honnan tudjuk, hogy segítségre szorul. Nekem a legszomorúbb az, amikor elmegyek az iskolába Gipsz Jakab ügyében beszélni, és a tanár azt mondja, hogy „Gipsz Jakab? Az semmi. Itt van Julika, meg Sára, meg Gizike." És elmondja mind a hármat, hogy milyen borzalmas körülmények között él és milyen rossz sora van. És akkor az a kérdés, hogy én ezt a három gyereket megkereshetem-e, és ha igen, akkor mit mondok, mit mondhatok, és kitől kaptam én felhatalmazást arra, hogy felajánljam a segítségemet. Ez volt a TECSA-ban folyó vitáknak nagyon tartalmas, szép oldala, de a kérdés teljes mértékben megválaszolatlan maradt. És akkor egy kicsit már elindultam afelé, hogy hogyan kerültem én a gyerekjóléti ellátásba a legeslegeslegeslegkezdetektől fogva.

Most áttérnék a harmadik kérdésre, hogy mi a helyzet a gyerekekkel. Tehát egy felnőtt dönthet úgy, hogy nem kér segítséget és elpatkol otthon, vagy nem otthon, hanem az utcán. Persze ezt nem gondolom teljesen komolyan, de valamennyire komolyan gondolom, hogy ezt megteheti, amíg felelösnek nevezhető az a döntése, hogy nem fogadja el a segítséget. De egy gyerek ügyében ki dönthet? Ugye a gyerek az nem tud dönteni, mert nem képes rá, de a szülei dönthetnek-e őróla? Nem volt nekem felhatalmazásom. És akkor elmondok két példát, ami a TECSA-ban valóban megtörtént, és ami arra késztetett, hogy belekapcsolódjam a gyermekvédelmi törvény megalkotásába, amennyire engedtek, illetve nagyon gyorsan átevezzek a gyerekjólétibe a családsegítőből és úgy gondolom, hogy a saját szakmai 
személyes történetem nem lenne teljes azok nélkül, amit eddig elmondtam. A két példa: Az történt, hogy a Terézvárosi Családsegítőben - megint korunkat nagyon megelőzve létrehoztuk azt a szervezetet, amit úgy hívtunk, hogy HAJCSA. Nem sikerült megtalálnom a dátumát, de biztos, hogy a kilencvenes évek legelején jött ez létre, talán kilencvenkettőben, ha jól számoltam vissza, az biztos, hogy az első polgármester regnálása alatt, tehát 94 előtt és 90 után. Ebben a családok átmeneti otthonában - ami kezdettől úgy müködött, mint a mai ilyen jellegü intézmények, holott törvény szerint ilyenek még nem voltak - élt egy gyerek, aki „,pechjére” feljött a családsegítőbe egy csoportra, elkezdett rajzolgatni és lerajzolt egy olyan jelenetet, ami egy gyerekpszichológus szemével egy azonnali kiemelést alátámaszt és megindokol. Temető, kés, halott, rettegő gyerek... Nem hiszem, hogy egy gyerekrajzot önmagában lehet értelmezni, de ordító volt a rajz mondanivalója. Mikor pedig utánakérdeztünk a dolognak, kiderült, hogy tényleg szörnyü, a gyerek számára megengedhetetlen dolgok történtek a családban. Azért használom a többes számot, mert Bárdos Kata volt a másik pszichológus - ö azóta is ott dolgozik, ő vezeti a TECSA-t - és ö is megrettent ettől a rajztól. Volt egy borzalmas teamvitánk arról, hogy van-e jogunk egy önként segítséget kérő hajléktalan család esetén egy gyerekkiemelési javaslatot írni a gyámhatóságnak, vagy ha nem írunk, akkor nem követünk-e el büncselekményt a dolog etikai értelmében. Akkor ezt a javaslatot megírtuk, de nem lettünk népszerüek a közösségben, és nem tudtuk meggyőzni a közösség minden tagját arról, hogy ilyenfajta felelösségünk is van a gyerek iránt.

A másik 1995-ben történt. A TECSA történetében - mióta én betettem a lábamat - minden évben volt egy nyári tábor, ami nagyon boldogságos és érdekes volt, és egy külön előadást is megérne. Minden évben körülbelül a második este döntöttünk úgy, hogy soha többet nem csinálunk nyári tábort - ahogy már korábban is eldöntöttük -, s a tábort követően egy hét is alig telt el, s mi már gondolkodtunk a következő éviről. Minden évben csináltunk, sőt ez kibővült nagyoknak vándortáborral, kicsiknek állótáborral, majd egy családi táborral, amit most is minden évben rendez a TECSA. 95-ben megjelent ott egy gyerek - hívjuk Krisztiánnak - tök egyedül és mondta, hogy az anyukája nem tudta elkísérni. És mikor elindultunk a Nyugati pályaudvar felé, akkor furcsa zörgést hallottunk Krisztián felöl. Rövidre zárva a dolgot: kiderült, hogy a csizmájában egy nejlonzacskó helyezkedett el, mert a zoknija vizes volt. Ebből a vonaton a beszélgetés során kiderült, hogy Krisztián anyja egy héttel az indulás előtt összebalhézott a nevelöapával, egy új pasival lett kapcsolata, de nem volt hol lakniuk, így elmentek a III. kerületbe, a Bécsi út fölött a hegyekben, valamilyen épülő háznak a felvonulási területén valamilyen zárható szobaként müködő magánmunkásszállóra. Ez a gyerek három napig teljesen egyedül volt ebben az idegen környezetben lévő szobában. Eszébe jutott, hogy indul a tábor, eszébe jutott, hogy neki nincs tiszta zoknija és kimosta, de az nem száradt meg, így azt a megoldást találta ki, hogy belehúzott egy nejlonzacskót, hogy ne legyen vizes a lába, mert tudta, hogy az nem jó. Tök egyedül pakolt be és maga sem tudta, hogy hogy került oda a TECSA-ba. Azt mondta, hogy hajnalban elindult és kérdezgette az embereket arról, amit tudott, hogy terézvárosi templom, és így szépen odatalált, mert fogalma nem volt, hogy hol van. Felhívtam az adott gyerek családjával foglalkozó családgondozót és azt mondtam, hogy mire hazajövünk, legyen kész a kiemelési javaslat. Ezt ő megtagadta - én voltam a fönöke -, de ő volt a teljes döntési jogkörrel rendelkező családgondozó, és azt mondta, hogy ezt nem lehet, mert a család önként jelentkezett. Mikor hazajöttünk, a pályaudvaron ott volt a gyerek anyja, és mielött én kinyithattam volna a számat, elvitte a gyereket. Akkor gondoltam úgy, hogy ezt nem lehet 
hagyni, ez így nincs jól. És az más kérdés, hogy mi történt ott a családsegítőben munkajogilag, meg a munka terén, meg etikailag... De akkor az én lelkem eljött a családsegítőből. Mert azt gondoltam, hogy a családgondozó a mi közösségünkben ezt joggal tehette meg. De ez nincs rendben, hogy megtehette. Akkor én úgy gondoltam, hogy gyerek, gyerek, gyerek, gyerek... És amikor a gyermekvédelmi törvény végül életbe lépett, és megalakult a XV. kerületben a gyerekjóléti, akkor egy kis kitérö után én oda pályáztam, meg is nyertem, azóta is ott vagyok ${ }^{2}$, azt a dolgot létrehoztam és vezetem. Hogy boldog lennék, azt nem mondanám az elmúlt két évben, de azt gondolom, hogy megtaláltam a helyemet. Az én szakmai életutam az a gyerekközpontú segítő munka, ahol együttmüködünk a szülővel, amíg a szülö képes együttmüködni a gyerek érdekében, de mihelyt ellene tesz, akkor a gyereket védem akár a családdal szemben, a család ellenében. Ennyit mondanék el. A gyerekjólétiben is vannak mindenféle izgalmak, de azt hiszem, hogy az nem szociálismunkatörténet, hanem a jelenkor.

Hallgató: Attól az még érdekes lehet.

R. M.: Még meséljek? Jó, akkor elmondom azt a három dolgot, amit aggasztónak tartok ma. Tíz évvel ezelött írtam a PhD-met ${ }^{3}$, és abban leírtam olyan feszültségeket, amik ma is nagyon erősen érezhetőek, amiből az egyik az, hogy a lépcsőzetesség elve visszavág. Kitalálódott egy olyan rendszer, amiben egymásra épül az alapellátás, a védelembe vétel, szakellátás. Ha a szülő együttműködik, képes és hajlandó valóságos segítséget elfogadni, változások folyamata elindul, akkor elég az alapellátás, ha nem, akkor a védelembe vétel, mint a guillotine ott lebeg a feje fölött és ezzel talán ki tudunk „nyomni” belőle egy valóságos együttmüködést, és ha ez se müködik, akkor a kiemelés, a szakellátás, a családtól való eltávolodás az egyetlen megoldás, és ez hozzátartozik a gyerekjóléti müködéséhez. Ha jól csinálja, akkor ugyanaz a szakember képes segítséget nyújtani a családtól már külön nevelkedő gyerek családjának, tehát segítséget tud nyújtani abban, hogy képesek és hajlandóak legyenek a gyereket visszafogadni. Ebben én hiszek. De elkezdett úgy müködni a rendszer - minél messzebb megyünk Budapesttől, annál inkább, de Budapesten is előfordul -, hogy hiába történik valami megengedhetetlen a gyerekkel, azt mondják, hogy legyen először alapellátás. Egy iskola jelez, hogy szarrá vertek egy gyereket, de a gyámhatóság nem hajlandó a kiemelési javaslatunkat elfogadni, csak azért, mert korábban nem voltunk kapcsolatban velük. És nem gondolja, hogy ez megengedhetetlen, tarthatatlan és türhetetlen, és nem lehet kitenni egy gyereket annak, hogy utána azért is megverjék, mert elmondta. Ezt én türhetetlennek tartom, és ez a kitalált lépcsőzetességnek a visszaütése.

A másik, hogy borzalmas megoldatlanságok vannak, amik nem változnak. Az egyik ilyen baj az iskolarendszer. Nem átlagos, nem szőke, nem kék szemü, nem mosolygós, nem jól szocializált gyerekeknek nincs kitalálva az iskola, bár vannak pedagógusok, akik nagyon profin kezelik az ilyen helyzeteket, de nem nagyon vannak iskolák, amik így kezelik, amelyek meg mégis - lásd a Burattino -, azok meg ellehetetlenülnek. Esetlegesen lehet ellátást szerezni egy-egy gyereknek, de a gyerekek ilyen jellegü problémái totálisan megoldatlanok. Az a tendencia, ami a mostani változásokban van, az nagyon nem örvendetes.

\footnotetext{
2013 tavaszán, az interjú készítésének idején - B. E.

${ }^{3}$ Révész Magda: A gyermekvédelmi alapellátás intézménytörténete Magyarországon. Kapocs, 2006., IV. V. VI. http://www.ncsszi.hu/kiadvanyok/kapocs-letoltheto--lapszamai/kapocs-2007/95/news, utolsó megnyitás: 2017. november 19.
} 
Más.

Ami eddig a gyerekvédelmi törvényben megvolt, hogy három szervezetnek kellett tévednie ahhoz, hogy rossz döntés szülessen egy gyerek ügyében - azaz a gyerekjólétinek, a jegyzői gyámhatóságnak meg a gyámhivatalnak -, az most kettőre redukálódott, és a második nagyon nagy hatalmúvá vált. A kormányhivatalokban összevonták a jegyzői gyámhatóság és a gyámhivatal feladatait; akik döntenek a gyerekek jólétéről, azok nem erre esküdnek fel, hanem kormánytisztviselők. Ez nem azért veszélyes, mert a kormány ilyen vagy olyan, hanem mert nem a gyerekekre tesznek esküt, a gyerekek érdekére, annak képviseletére ahogy mi még erre tettünk esküt -, hanem a kormányra, nem is köztisztviselök, hanem kormánytisztviselők. Én nagyon pesszimista vagyok ebben a vonatkozásban. Ezt gondoltam elmondani nektek mint személyes szociálismunka-történet.

Hallgató: Nekem úgy tünt, hogy a kezdetekhez képest toporog a rendszer, mintha nem lett volna ilyen nagy ,aha”-élményed.

R. M.: Nekem nagyon nagy ,aha”-élményem volt 1997-től 2005-ig. Nagyon fejlödött a gyerekjólétis szakma, nagyon sok mindent megújítottak a törvényben is, sok együttmüködés volt a törvényalkotók és a terepen dolgozó szakemberek között, sok együttmüködés alakult. A döntéshozók nagyon alapoztak a terep szakembereinek véleményére, ami például az úgynevezett macis adatlapokban erősen nyomon követhető. Átnyomta a szakma a macis adatlapok megújítását. Gyámhatóság, gyámhivatal, szakellátás, a szakellátás intézményrendszere, gyerekjóléti, átmeneti gondozó intézmények közösen dolgoztak azon, hogy olyanok legyenek a macis adatlapok, amilyeneknek lenniük kellene. Sok kompromisszummal, de megegyeztünk, és azt egy az egyben elfogadták. Két nevet tudok mondani: Göncz Kinga mint miniszter nagyon sokat tett azért, hogy a szakma szava hallatszódjék ott legfölül, és Gáspár Károly, aki a Gyermekvédelmi Főosztály vezetője volt több menetben. Az ő halála nagyon megrázta a szakma fejlödését, és erősen meg is bicsaklott attól kezdve. Azóta nagyon erősen azt érzem, hogy mi, akik a terepen dolgozunk, és a terep tapasztalatait tudnánk becsatornázni a törvényhozásba, a szőnyeg alá vagyunk söpörve. Ami most történik például az 50 órányi igazolatlan hiányzások kapcsán, az felháborító. A dolog úgy van kitalálva, hogy mikor a gyerek másodszor hiányzik az iskolából, akkor az iskola ír egy levelet a gyerekjólétinek. Ez még fakadhat abból, hogy a gyerek kétszer elkésett - két igazolatlan óra. Ekkor a gyerekjóléti még csinál, amit akar, ez nincs a törvényben lefektetve. De mikor már tíz óra hiányzás összegyülik, akkor az iskola ír a gyerekjólétinek, a szabálysértési hatóságnak, a gyámhivatalnak. A gyámhivatal és a szabálysértési hatóság megfenyegeti a szülőket, a gyerekjóléti intézkedési tervet csinál, amiben leírja, hogy mit tesz a család, gyerekjóléti és az iskola annak az érdekében, hogy a gyerek ne hiányozzon igazolatlanul az iskolából. Miért baj ez? Ki tudna tenni azért, hogy a gyerek járjon iskolába? Nem az iskolát kellene megváltoztatni? Az iskola nem tudja elérni azt, hogy a gyerekek bele akarjanak járni, és akkor eköré húznak egy lufit, ahelyett, hogy a segítséget elfogadó gyerekek gondjaival foglalkoznának, mindenki leveleket meg intézkedési terveket ír, totál feleslegesen, mert egy szociális munkás az esetek jelentős részében nem tud azért tenni, hogy az iskola befogadóbb legyen, és a gyerekek szeressenek oda járni. Irkáljuk a rengeteg fecnit, mert nem mernek nekimenni az oktatási rendszernek, ami úgy rossz, ahogy van. Persze van olyan eset, amikor az igazolatlan hiányzás kapcsán a látókörünkbe kerülő gyerek családjánál egyéb gondok is vannak, de az a kérdésem, miért nem az egyéb gondot jelezte az iskola, 
miért azt a 2 igazolatlan órát. Nem tudom, azt a Zöld könyvet ${ }^{4}$ ismeritek-e, ami annak az oktatási kerekasztalnak az összefoglalója, melyen szociológusok, oktatáskutatók, terepen dolgozó szakemberek, oktatók, szociális munkások vettek részt. Ebben összeállt az a komplex problémahalmaz, ami az iskolákban megjelenik, ami úgy kezdődik, hogy a pedagógus szakra jelentkezők kiválasztása kontraszelektív. Aki befejezi az egyetemet, azok közül, aki elmegy tanítani, az a következő kontraszelekció, és létrejön egy olyan gárda - amit a börömön is tapasztaltam -, ahol véletlenszerüen vannak jó tanárok. A jók kipörögnek a legtöbb oktatói csoportból, mert ők válnak rögtön feketebáránnyá, mert ők azok, akik olyan problémákat hoznak be a tantestületbe, amit a tantestület nem szeret hallani. Ez csak az egyik szelete a dolognak. A másik az, hogy bölcsődés kortól kezdve olyan módon próbálják „megerőszakolni” a szülőket - belegyalogol a szülők kompetenciájába a védőnő, a bölcsőde és aztán az óvoda. Hogy hogy etesse, hogy szeresse, hogy bánjon vele, és nem tudom én, még mit csináljon. Ettől a legkisebb kortól kezdve kérdés, hogy milyen a tananyag. Kimutatták, hogy a matematikakönyvek első osztályban olyanok, aminek a kérdéseit a jól szocializált gyerekek értik meg. Van egy olyan feladat, hogy számold meg, hány labda van az asztal alatt. Nem hülye a gyerek, és nem az a baj, hogy nem tudja megszámolni, hanem nem tudja, mit jelent az, hogy alatt, vagy nem tudja, mi az asztal. Arra senki nem figyel oda, hogy minden szubkultúrában más az alap és más, amit megosztanak a gyerekkel, belenevelnek a gyerekbe. És nem tudják rászánni magukat, hogy még az iskola elött teremtsenek egy olyan közös alapot, amire alapozva aztán az iskolában már a matematikát tudnák tanítani. Mert egy olyan pedagógus, aki hozott anyagból dolgozik, az rögtön meglátja, hogy te nem tudod, mi az, hogy asztal. És tudja, hogy akkor ezzel kell foglalkoznia és lehet, hogy nem fog labdát számoltatni az első három hónapban.

Hallgató: Mondtad, hogy pszichológus vagy és családgondozó. Te hogy érzed magadban ezt a kettőt?

R. M.: Én nagyon hamar nem voltam pszichológus. A legjobb időszakom az volt, amikor családgondozóként tevékenykedtem és volt egy-két páciensem, akivel lehetett ezt a laborpszichoterápiát csinálni. Én nagyon szerettem pszichológusként dolgozni, de erre már évek óta nincs lehetőségem, de elhatároztam, hogy ezen változtatni fogok. Az is egy nagyon izgalmas menet, olyan emberekkel foglalkozni, akik éppen pszichológusi segítséget tudnak elfogadni. De az az út most nem boldogítana engem. Én nagyon jól döntöttem, hogy elléptem onnan. Ezt tudom mondani, és le is járt az időnk.

B. E.: Nagyon szépen megköszönjük.

\footnotetext{
${ }^{4}$ Fazekas Károly, Köllő János, Varga Júlia (szerk.) (2008): Zöld könyv a magyar közoktatás megújitásáért. Ecostat, Budapest, http://mek.oszk.hu/08200/08222/08222.pdf, utolsó megnyitás 2017. november 19.
} 